\title{
The Evaluation of Prevalence, Extension and Severity of Gingival Recession among Rural Nepalese Adults
}

\author{
Dr Manoj Humagain,' Dr Dashrath Kafle² \\ 'Asst Professor, Dept of Periodontology, ${ }^{2}$ Asst Professor, Dept of Orthodontics \\ Kathmandu University School of Medical Sciences, Dhulikhel, Nepal
}

\section{ABSTRACT}

Introduction: Gingival recession is the location of marginal periodontal tissues apical to the cemento-enamel junction, which can lead to many clinical problems. The prevalence, extension and severity of gingival recession present considerable differences among various study populations.

Objective: To assess the prevalence, extension and severity of gingival recession among rural Nepalese adults.

Materials \& Method: The study was performed on 246 adult dentate rural patients above 20 years of age having at least 24 natural teeth. The prevalence, extension and severity of gingival recession were assessed by a single examiner using William's graduated periodontal probe. Type and severity of gingival recession was recorded by using Miller's criteria of apico-coronal height of recession defects.

Result: Gingival recession was present in $65.44 \%$ of the total study sample and mean number of teeth with gingival recession was 9.77 . The prevalence of gingival recession was $41.37 \%, 58.90 \%, 77.41 \%$ and $86.79 \%$ in age groups of 20-29 years, 30-39 years, $40-49$ years and $\geq 50$ years respectively. In younger age groups Class I gingival recession was more prevalent whereas Class III and Class IV gingival recession was more prevalent in older age groups. Mandibular central incisors were the teeth most frequently affected by gingival recession (7.3\%).

Conclusion: $9.64 \%$ of teeth were affected by severe form of gingival recession at the age group $20-29$ years as compared to $48.09 \%$ at the age groups more than 50 years. High prevalence of gingival recession in adult subjects provides information about the importance of diagnosis and knowledge on these pathological gingival changes.

Key words: apico-coronal, extension, prevalence, recession, severity

\section{INTRODUCTION}

Gingival recession is defined as location of marginal periodontal tissues apical to cemento-enamel junction. ' Recession may be localized to one tooth, or a group of teeth, or may be generalized throughout the oral cavity. ${ }^{2}$ It may be associated with apical shift of marginal gingiva on one or more surfaces resulting in clinical attachment loss and root exposure that can lead to clinical problems such as root surface sensitive to hot and cold, caries, cervical root abrasions, erosions, plaque retention and aesthetic concern to the patient. Several factors play role in recession development such as excessive or inadequate teeth brushing, destructive periodontal disease, tooth malpositioning, alveolar bone dehiscence, thin marginal tissue covering a non-vascularized root surface, shallow vestibule, inadequate width of attached gingiva, frenal pull and trauma from occlusion. ${ }^{3}$

Despite common observation in adults; the prevalence, extension and degree of severity of gingival recession present considerable differences among various study populations. Prevalence indicates number of cases or occurrences of gingival recession; extension corresponds to the number of teeth affected by gingival recession; and severity signifies the total root surface exposed by the gingival recession, i.e. the linear apico-coronal height of the gingival recession. 
The proportion of subjects with gingival recession increases with age; $4,5,6,7,8$ the incidence varies from $8 \%$ in children to $100 \%$ after the age of 50 years. ${ }^{9}$ As the incidence and severity of recession increases with age, some investigators assumed that recession may be a physiologic process related to aging. However, convincing evidence for a physiologic shift of the gingival attachment has never been presented. ${ }^{2}$ The gradual apical shift of marginal gingiva is most probably the result of the cumulative effect of minor pathologic involvement and/or repeated minor direct trauma to the gingiva, or may be the result of increasing periodontal disease in some population without access to dental care. ${ }^{10}$

Many epidemiologic studies have been conducted on prevalence and severity of gingival recession on western population. According to US National Survey," $88 \%$ of seniors (aged 65 years and above) and $50 \%$ of adults (18 to 64 years) present recession in one or more sites; progressive increase in frequency and extent of recession is observed with increase in age. The prevalence varied from 50-90\% among these populations. In Norway ${ }^{12} 51 \%$ of adults aged 18 years and above had gingival recession, while similar studies among adults in Iraq $^{13}$ and Finland ${ }^{14}$ displayed gingival recessions in $73 \%$ and $68 \%$ subjects respectively. Similarly, gingival recession was observed in $53.5 \%$ Greek adults, ${ }^{15} 76 \%$ Indian samples ${ }^{16}$ and $60.5 \%$ Yemeni adults. ${ }^{17}$

Periodontal disease is more common in developing countries than in developed countries. Since recession is one of the characteristic features of periodontal disease, its prevalence and severity is of great concern. The aim of this study was to assess the prevalence, extent and severity of gingival recession among rural Nepalese patients.

\section{MATERIALS AND METHOD}

The study sample comprised of 246 adult subjects aged above 20 years randomly selected from the patients attending diagnosis and treatment camps organized by Department of Dentistry, Kathmandu University Teaching Hospital at Kushadevi VDC of Kavre district on $16^{\text {th }}$ March 2013. The participants were divided into following four groups according to age range:

\begin{tabular}{|l|c|l|}
\hline Group 1 & $20-29$ years & 58 patients \\
\hline Group 2 & $30-39$ years & 73 patients \\
\hline Group 3 & $40-49$ years & 62 patients \\
\hline Group 4 & $>50$ years & 53 patients \\
\hline
\end{tabular}

The selection criteria comprised of age above 20 years with minimum number of 24 natural teeth present excluding third molars. The participants were evaluated by a single examiner to avoid inter-examiner variations. The sample included 137 male and 109 female, adding up to 6,731 teeth for examination. William's graduated periodontal probe was used for the measurement of apico-coronal height of gingival recession, which was recorded when greater than 1 $\mathrm{mm}$ of root surface was exposed. Four surfaces were evaluated on each tooth: mesial, buccal, distal and lingual. Linear measurements were obtained from the cemento-enamel junction to the gingival margin of the teeth presenting with gingival recession in order to evaluate the apico-coronal height of the gingival recession. In cases where cemento-enamel junction was covered by calculus or hidden by a restoration or lost due to caries or cervical abrasion; the location of such junction was estimated on the basis of adjacent tooth.

\section{Miller's Classification of gingival recession}

\begin{tabular}{|l|l|}
\hline Class I & $\begin{array}{l}\text { Marginal tissue recession without extending to the muco-gingival junction without loss of bone or } \\
\text { soft tissue in the interdental areas }\end{array}$ \\
\hline Class II & $\begin{array}{l}\text { Marginal tissue recession that extends to or beyond the muco-gingival junction without loss of bone } \\
\text { or soft tissue in the interdental areas }\end{array}$ \\
\hline Class III & $\begin{array}{l}\text { Marginal tissue recession that extends to or beyond the muco-gingival junction in addition there is } \\
\text { bone and/or soft tissue loss in the interdental areas and/or mild malocclusion }\end{array}$ \\
\hline Class IV & $\begin{array}{l}\text { Marginal tissue recession that extends to or beyond the muco-gingival junction with severe bone } \\
\text { and/or soft tissue loss in the interdental areas and/or severe tooth malposition }\end{array}$ \\
\hline
\end{tabular}


Three categories were established according to apico-occlusal dimension of the root surface exposed by gingival recession; small recessions: less than $3 \mathrm{~mm}$ of root surface exposed; moderate recessions: 3 to 4 $\mathrm{mm}$ of root surface exposed; advanced recessions: more than $4 \mathrm{~mm}$ of root surface exposed to the oral environment. Gingival recession was recorded according to P.D. Miller's classification ${ }^{18}$ of marginal tissue recession.

\section{RESULTS}

The study revealed gingival recession in 161 subjects out of 246 , which is $65.44 \%$ of the total sample examined. Among 6731 teeth of the 246 subjects examined; 2404 displayed gingival recession corresponding to $35.72 \%$ of the total teeth examined. Among all subjects mean number of teeth with gingival recession was 9.77 and gingival recession was observed in 4336 sites with the mean number of sites of gingival recession per subject as 17.63 (Table 1).

Prevalence of gingival recession increased with age. Among the study sample, the prevalence of gingival recession was $41.37 \%, 58.90 \%, 77.41 \%$ and $86.79 \%$ in age groups of 20-29 years, 30-39 years, 40-49 years and $\geq 50$ years respectively. Increase in age also led to increase in the mean number of teeth with gingival recession. The mean number of teeth with gingival recession at the age group above 50 years (63.94\%) was significantly higher than that of age group 20-29 years (10.28\%). Similarly the extension of gingival recession was also found to be increased with age. The mean number of teeth with gingival recession per subject at 20-29 years age group (2.86) was significantly less than at the age groups above 50 years (17.26) (Table 1).

Among age groups 20-29 and 30-39 years, Class I gingival recession was more prevalent i.e. $80.12 \%$ and $78.46 \%$ respectively whereas Class III and Class IV gingival recessions were more prevalent in older age groups (Table 2). Only $1.20 \%$ of subjects of age groups 20-29 had Class IV gingival recession as compared to $40.11 \%$ at the age groups above 50 years. At the older age groups more than 50 years; Class III and Class IV gingival recessions were $39.12 \%$ and $40.11 \%$ respectively, whereas only $12.79 \%$ subjects had Class II gingival recession and $7.98 \%$ subjects had Class I gingival recession (Table 2). Among all teeth examined, mandibular central incisors were the teeth most frequently affected by gingival recession (7.3\%) followed by maxillary first molars, second premolars and first premolars. Maxillary incisors and second molars were least affected by gingival recession (Table 3). Similarly the severity of gingival recession (based on apico-coronal height of recession) increased with age. Only $9.64 \%$ of teeth were affected by severe form of gingival recession ( $>4 \mathrm{~mm}$ ) at age group 20-29 as compared to $48.09 \%$ at the age groups above 50 years (Table 4).

Table 1: Prevalence and extension of gingival recession according to age group

\begin{tabular}{|c|c|c|c|c|c|c|}
\hline \multirow[b]{2}{*}{$\begin{array}{l}\text { Age Group } \\
\text { (years) }\end{array}$} & \multirow[b]{2}{*}{$\begin{array}{l}\text { Total no. } \\
\text { of teeth }\end{array}$} & \multicolumn{2}{|c|}{ Prevalence } & \multicolumn{3}{|c|}{ Extension } \\
\hline & & $\begin{array}{l}\text { No. of Subjects } \\
\text { with GR }\end{array}$ & $\begin{array}{c}\text { No. of teeth with } \\
\text { GR }\end{array}$ & $\begin{array}{c}\text { Mean no. of } \\
\text { teeth with GR/ } \\
\text { subject }\end{array}$ & $\begin{array}{l}\text { No. of } \\
\text { sites with } \\
\text { GR }\end{array}$ & $\begin{array}{c}\text { Mean no. of } \\
\text { sites of GR/ } \\
\text { subject }\end{array}$ \\
\hline $20-29(N=58)$ & 1615 & 24 (41.37\%) & $166(10.28 \%)$ & 2.86 & 186 & 3.2 \\
\hline 30- $39(N=73)$ & 1988 & 43 (58.90\%) & $520(26.16 \%)$ & 7.12 & 857 & 11.73 \\
\hline $40-49(\mathrm{~N}=62)$ & 1697 & $48(77.41 \%)$ & 803 (47.32\%) & 12.95 & 1427 & 23.02 \\
\hline$\geq 50(N=53)$ & 1431 & $46(86.79 \%)$ & 915 (63.94\%) & 17.26 & 1866 & 35.21 \\
\hline Total $(N=246)$ & 6731 & $161(65.44 \%)$ & 2404 (35.72\%) & 9.77 & 4336 & 17.63 \\
\hline
\end{tabular}


Table 2: Scoring of the severity of gingival recession based on Miller's classification

\begin{tabular}{|c|c|c|c|c|c|}
\hline \multirow{2}{*}{$\begin{array}{c}\text { Age Group } \\
\text { (years) }\end{array}$} & \multicolumn{5}{|c|}{ Severity of Gingival Recession } \\
\cline { 2 - 5 } & Class I & Class II & Class III & Class IV & \multirow{2}{*}{ Total } \\
\hline $20-29$ & $133(80.12 \%)$ & $23(13.86 \%)$ & $8(4.82 \%)$ & $2(1.20 \%)$ & 166 \\
\hline $30-39$ & $408(78.46 \%)$ & $63(12.12 \%)$ & $37(7.11 \%)$ & $12(2.31 \%)$ & $\mathbf{5 2 0}$ \\
\hline $40-49$ & $185(23.04 \%)$ & $241(30.01 \%)$ & $254(31.63 \%)$ & $123(15.32 \%)$ & $\mathbf{8 0 3}$ \\
\hline$\geq 50$ & $73(7.98 \%)$ & $117(12.79 \%)$ & $358(39.12 \%)$ & $367(40.11 \%)$ & 915 \\
\hline Total & $\mathbf{7 9 9 ( 3 3 . 2 4 \% )}$ & $\mathbf{4 4 4}(\mathbf{1 8 . 4 7 \% )}$ & $\mathbf{6 5 7}(\mathbf{2 7 . 3 3 \% )}$ & $\mathbf{5 0 4}(\mathbf{2 0 . 9 6 \% )}$ & $\mathbf{2 4 0 4}$ \\
\hline
\end{tabular}

Table 3: Intraoral distribution of gingival recession

\begin{tabular}{|c|c|c|c|c|c|c|c|c|c|c|c|c|c|c|c|}
\hline$\%$ & 2.4 & 4.6 & 4.3 & 4.2 & 3.3 & 1.7 & 2.2 & 2.2 & 1.6 & 3.4 & 4.5 & 4.1 & 4.5 & 2.3 & 45.3 \\
\hline \multirow{2}{*}{$\begin{array}{c}\text { Teeth } \\
\text { No. (FDI) }\end{array}$} & 17 & 16 & 15 & 14 & 13 & 12 & 11 & 21 & 22 & 23 & 24 & 25 & 26 & 27 & \multirow{2}{*}{ Total \% } \\
\hline & 47 & 46 & 45 & 44 & 43 & 42 & 41 & 31 & 32 & 33 & 34 & 35 & 36 & 37 & \\
\hline$\%$ & 1.9 & 3.4 & 2.8 & 2.8 & 3.5 & 5.7 & 7.3 & 7.3 & 5.6 & 3.4 & 2.7 & 2.9 & 3.6 & 1.8 & 54.7 \\
\hline
\end{tabular}

Table 4: Severity of gingival recession according to age groups

\begin{tabular}{|c|c|c|c|c|}
\hline $\begin{array}{c}\text { Age group } \\
\text { (Years) }\end{array}$ & $\begin{array}{c}\text { No of teeth with GR } \\
<\mathbf{3 m m}\end{array}$ & $\begin{array}{c}\text { No of teeth with GR } \\
\mathbf{3 - 4} \mathbf{~ m m}\end{array}$ & $\begin{array}{c}\text { No of teeth with GR } \\
\mathbf{>} \mathbf{~ m m}\end{array}$ & Total \\
\hline $\mathbf{2 0 - 2 9}$ & $119(71.69 \%)$ & $31(18.67 \%)$ & $16(9.64 \%)$ & 166 \\
\hline $\mathbf{3 0 - 3 9}$ & $322(61.92 \%)$ & $127(24.43 \%)$ & $71(13.65 \%)$ & 520 \\
\hline $\mathbf{4 0 - 4 9}$ & $208(25.90 \%)$ & $231(28.77 \%)$ & $364(45.33 \%)$ & 803 \\
\hline $\mathbf{2 5 0}$ & $54(5.90 \%)$ & $421(46.01 \%)$ & $440(48.09 \%)$ & 915 \\
\hline
\end{tabular}

\section{DISCUSSION}

The result of the present study corroborates previous findings of the common occurrence of gingival recession in adult subjects. This study confirms that the prevalence and severity of gingival recession increase with age; which is consistent with most of the epidemiological studies on several age groups. ${ }^{10,19,20,21,22}$ This study reports 161 (65.44\%) subjects found to be affected with gingival recession which is consistent with several other related studies, $, 16,17,21$ and the prevalence is slightly higher than the findings of some other studies. 312,22 Other studies reported the prevalence of gingival recession ranging from $22.5 \%$ to $27.7 \% .^{5,23}$ The relationship between increased prevalence of gingival recession and age could be due to the cumulative effect of age, periodontal disease and longer period of exposure to the agents that cause gingival recession.

The extension of root surface exposure due to the apical shift of marginal gingiva defines severity of gingival recessions. ${ }^{24,25,26}$ Miller $^{18}$ suggested the classification of gingival recession based on extension of recession defects and the extent of hard and soft tissue loss surrounding the gingival recession defects. For Millers' class versus age group; our study shows that Millers' Class I was associated with the largest number of cases having gingival recessions in the sample. Class III and Class IV gingival recessions; which are considered as the most severe forms of gingival 
recession were increasingly prevalent in older subjects. Similar findings were also seen in the previous studies of gingival recession. ${ }^{17,21,27}$

The present study demonstrated higher prevalence of gingival recession in mandibular teeth (54.70\%) as compared to maxillary teeth (45.30 \%); which is in agreement to the findings of previous studies. ${ }^{14,16,27}$ However, study report by Gorman ${ }^{19}$ contradicts this result with the reverse findings showing higher prevalence in maxillary teeth (56\%). Lower occurrence of gingival recessions in maxillary teeth is probably related to the characteristics of keratinized mucosa, which is wider and thicker in maxilla than in the mandible. ${ }^{28}$ In agreement to several other studies, no differences were observed in the occurrence of gingival recession between right and left sides. 14,16,27

In our study, mandibular central incisors displayed the highest frequency of gingival recession (7.3\%). Besides, mandibular lateral incisors, premolars, maxillary and mandibular first molars were also commonly affected. Many recent epidemiological studies on distribution of gingival recession also demonstrated similar findings. 315,29 However, no consensus is observed in the literature in regards to the teeth most frequently affected by gingival recession. Some indicated maxillary canines and premolars, 19,30 other mentioned maxillary premolars and molars ${ }^{8,26}$ as the most frequently affected teeth by gingival recession. A study done by Crysanthakopulous ${ }^{15}$ on Greek adults found that maxillary and mandibular first and second molars were the most frequently affected tooth by gingival recession. In agreement to the findings of other epidemiological studies, the present study also yields the finding that the severity of gingival recession based on apico-coronal height of recession increases with age..$^{15,16,27}$

\section{CONCLUSION}

Gingival recession was observed in $65.44 \%$ of the sample and $35.71 \%$ of the total teeth examined among Nepalese rural subjects. The mean number of teeth and mean number of sites with gingival recession and the severity of the gingival recession based on the apicocoronal height of recession are directly proportional to the age of the subject. Mandibular central incisors were the teeth most frequently affected by gingival recession. Greater prevalence, extension and severity of gingival recession observed in older subjects suggest the cumulative effect of the lesion associated with longer period of exposure to the etiologic agents. Timely identification of condition and removal of the etiology is necessary to reduce or avoid such gingival alteration. More analytic and longitudinal study with larger sample size is required to elucidate the finding of the present study.

OJN 


\section{REFERENCES}

1. Glossary of Periodontal Terms. American Academy of Periodontology, 4th edition; $\mathrm{p} 44$.

2. Newman MG, Klokkevold PR, Takei HH, Carranza FA. Carranza's Clinical Periodontology; Saunders, 11 th edition; 2012 , p 82.

3. Dilsiz A, Aydin T. Gingival recession associated with orthodontic treatment and root coverage. J Clin Exp Dent 2010; 2:20-32.

4. Kassab MM, Cohen RE. The etiology and prevalence of gingival recession. J Am Dent Asso 2003; 134(2): 220-225.

5. Arowojolu MO. Gingival recession at the University College Hospital, Ibadan- prevalence, and effect of some aetiological factors. Afr J Med Sci 2000 Sept- Dec; 29 (3-4): 259- 63.

6. Hosanguan C, Ungchusak C, Leelasithorn S, Prasertosm P: The extent and correlates of gingival recession in non-institutionalized Thai elderly. J Int Acad Periodontol 2002 Oct; 4 (4): 143-8

7. Susin C, Haas AN, Opperman RV, Hangejorden O, Albandor JM. Gingival recession: epidemiology and risk indicators in a representative Urban Brazillian population. J Periodontol 2004 Oct; 75(10): 1377-86.

8. Serino G, wennstrom JL, Lindhe J, Eneroth L. The prevalence and distribution of gingival recession in subjects with high standard of oral hygiene. J Clin Periodontol 1994 Jan; 21 (1): 57-63.

9. Woofter. The prevalence and etiology of gingival recession. Periodont Abstr. 1969; 17: 45.

10. Anerud $\mathrm{A}$, Boysen $\mathrm{H}$. The natural history of periodontal disease in man: prevalence, severity and extent of gingival recession. $J$ Periodontol 1992 Jun; 63: 489- 495.

11. Miller AJ, Brunelle A, Carlos JP, Brown LJ, Loe H. Oral health of United States Adults: The national survey of oral health in US employed adults and seniors 1985-1986; NIH Publication No 87- 2868.

12. Sangnes G, Gjermo P. Prevalence of oral soft and hard tossue lesions related to mechanical tooth cleansing procedures. Community Dent Oral Epidemiol 1976 Mar; 4 (2): 77-83.

13. Tarik Y, Ghada DH, Layla A. Prevalence of gingival recession in adult population in Mosul city-Iraq. J Coll Dent 2002; 13: 24-30.

14. Vehkalathi M. occurrence of gingival recession in adults. J Periodontol 1989 Nov; 60 (11): 599-603.

15. Chrynsanthakopoulos NA. Occurrence, extension and severity of gingival recession in a Greek adult population sample. J Periodontol Implant Dent 2010; 2(1): 37-42.

16. Anarthe R, Mani A, Marawar PP. Study to evaluate prevalence, severity and extension of gingival recession in the adult population of Ahmednagar District of Maharastra State in India. Journal of Dental and Medical Sciences 2013; 6(1): 32-37.

17. Amran GA, Atta SAM. Statistical analysis of the prevalence, severity and some possible etiologic factors of gingival recessions among the adult population of Thamar city, Yemen. RSBO 2011; 8(3): 305-13.

18. Miller PD. A classification of marginal tissue recession. Int J Perio Resto Dent 1984; 5(2): 8-13.

19. Gorman WJ. Prevalence and etiology of gingival recession. J Periodontol 1967; Jul/ Aug; 38(4): 316-22.

20. Seefeld G, Kuhn H, Kuhn A. Studies on the prevalence of gingival recession in juveniles at the age from 15 to 25 years in consideration of preventive case. Stomatol DDR 1990; 40: 258-60.

21. Guimaraes MG, Aguiar EG. Prevalence and type of gingival recession in adults in the city of Divinopolis, MG, Brazil. Braz J Oral Sci 2012; 11 (3): 357-361.

22. O'Leary TJ, Drake RB, Crump PP, Allen MF. The incidence of recession in young males; a further study. J Periodontol 1971 May; 42(5): 264-7.

23. Muller HP, Stadermann S, Heineeke A. gingival recession in smokers and non-smokers with minimal periodontal disease. J Clin Periodontol 2002 Feb; 29(2): 129-36.

24. Kennedy JE, Bird WC, Palcanis KG, Dorfman HS. A longitudinal evaluation of varying widths of attached gingiva. J Clin Periodontol 1985 Sept; 12(8): 667-75.

25. Van Palestein, Helderman WH, Lembariti BS, Van der Weijden GA, Van't Hof MA. Gingival recession and its association with calculus in subjects deprived of prophylactic dental care. J Clin Periodontol 1998; 25(2): 106- 111.

26. Joshipura KJ, Kent RL, DePaola PF. Gingival recession: Intraoral distribution and associated factors. J Periodontol 1994 Sept; 65(9): 864-71.

27. Marini GM, Greeghi Sebastie AL, Passanezi E, Santana Adriana PC. Gingival recession: prevalence, extension and severity in adults. J Appl Oral Sci 2004; 12(3): 250-5.

28. Tanerbaum H. A clinical study comparing the width of attached gingiva and prevalence of gingival recessions. J Clin Periodontol 1982 Jan; $9(1): 86-92$.

29. Badea AR. Gingival recession at dental college hospital Al- Mustansiriya University; Prevalence and effect of some associated factors. Malaysian Dental Journal 2007; 4(2): 117-24.

30. Addy M, Mostafa P, Newcombe RG, Dentine hypersensitivity: the distribution of recession, sensitivity and plaque. J Dent 1986 Dec; 15(6): 242-8. 